\title{
WOOD AND BUILDING CONSTRUCTION IN THE CONVENT OF VILAR DE FRADES (BARCELOS, PORTUGAL): THE BEAM SYSTEMS OF THE 16TH CENTURY
}

\author{
ANTÓNIO PEREIRA ${ }^{(1)}$
}

Abstract:

The monastic and conventual complex of S. Salvador de Vilar de Frades, located in the municipality of Barcelos (Portugal), has an attested occupation since the 11 th century. As a result of the different constructive phases, the current edification integrates a diversified group of material and raw material applied according to different construction techniques.

Through a methodological approach that favours the intersection between different types of sources, the present article aims to analyse wood as building construction material in Vilar de Frades, namely in the beam systems of the 16th century, as well as in the long-term articulation between liturgical furniture and the edification.

Keywords: Wood resources; Vilar de Frades; construction; liturgical furniture; beam systems; Archaeology; History of Construction; $16^{\text {th }}$ century

Resumo:

Madeira e construção no convento de Vilar de Frades (Barcelos, Portugal): os sistemas de vigas do século XVI O complexo monástico-conventual de S. Salvador de Vilar de Frades, localizado no concelho de Barcelos (Portugal), possui uma ocupação atestada desde o século XI. Em resultado das diferentes fases construtivas, a edificação atua integra um conjunto diversificado de materiais e matérias-primas aplicadas de acordo com diferentes técnicas construtivas.

Através de uma abordagem metodológica que privilegia o cruzamento de diferentes tipos de fontes, o presente artigo tem por objetivo analisar a madeira enquanto material de construção presente em Vilar de Frades, nomeadamente nos sistemas de vigas do século XVI, bem como na articulação de longa duração existente entre o mobiliário e a edificação.

Palavras-chave: Recursos de madeira; Vilar de Frades; mobiliário litúrgico; sistemas de vigas; Arqueologia; História da Construção; século XVI

\section{INTRODUCTION}

The present article $^{1}$ emerges from a research currently in development that aims to study the characteristics of monastic and conventual building construction in the northwest of the Iberian Peninsula between the medieval period and the present, under the multidisciplinary perspective of fields like Archaeology and History of Construction.

Adopting the Convent of Vilar de Frades (Barcelos, Portugal) as a case study, our pretention is to develop an analysis about the presence of wood throughout the diachronically documented constructive moments of the convent, incorporating the fairly heterogenic use of wood associated to building construction with the objects of liturgical function and quotidian use.

The article's structure starts with the geographic and historical contextualization of the convent of Vilar de Frades, followed by the methodological approach employed to the subject under analysis. Then, focusing on the references related to wood and woodwork between the $16^{\text {th }}$ and $19^{\text {th }}$ century, the broad perspective about the presence of wood in the buildings of the convent comes through a chronologically sequenced compilation contemplating aspects such as the woodworking developed, the diversity of the wood used as raw material and the professional component (specialization and hierarchical organization).

The main focus of our analysis regards the south wall on the cloister south to the church. A remaining part of the $16^{\text {th }}$ century cloister, which today stands as a ruin and as an indispensable material source to the study of the evolution of the constructive characterization of the building.

Taking in consideration the perishable nature of wood, the remaining constructive elements in this wall constitute, almost paradoxically, an indispensable material source for the comprehension of the wood beam systems used in the in the $16^{\text {th }}$ century. For this matter, we intend to approach the sudden transformation that occurs in the cloister area in the aforementioned period, in order to interpret the remains in its proper context and explicit the changes occurred in the beam systems.

In conclusion, we aim to evoke the potential of the application of the archaeological methods, inside a multidisciplinary approach, as a contribution to the investigation of historical buildings and

(1) FCT PhD studentship holder (SFRH/BD/110434/2015), Lab2PT - ICS Universidade do Minho. Email: aammpsp@gmail.com

${ }^{1}$ This work has the support of the Project Lab2PT - Landscapes, Heritage and Territory laboratory - AUR/04509 and FCT through national funds and when applicable of the FEDER co-financing, in the aim of the new partnership agreement PT2020 and COMPETE2020 - POCI 010145 FEDER 007528 
constructions related to the use of wood in monasteries and convents.

\section{THE GEOGRAPHICAL AND HISTORICAL CONTEXT OF VILAR DE FRADES}

The convent of Vilar de Frades is located in the parish of Areias de Vilar, municipality of Barcelos (Portugal). Implanted on the right bank of the Cávado river, in a rural landscape, the complex is presently limited by a fence that includes an area of approximately 9 ha of terrain (Fig. 1).

In terms of the geomorphology, with altitudes ranging from $15 \mathrm{~m}$ to $100 \mathrm{~m}$, the convent occupies a valley that outlines a shape which resembles an "amphitheatre" facing the river.

Inside the convent's territory, there is a rather visible demarcation between the areas of farm and the areas of forest. In the 17th century, Francisco de Santa Maria, while describing the convent's circuit, referred the existence of chestnut trees and oaks, as well as a forest area inside the fence composed by numerous large trees like pines, mainly in an attempt to emphasise the qualities of the wood ${ }^{2}$. Continuing with his description, several other species are mentioned, including cypresses, plane trees, myrtle trees and boxwood, among others. (MARIA 1697).
Historically, Vilar de Frades is intricately linked to the Christian monastic medieval phenomenon of the peninsular west. Occupying the now extinct parish of San Salvador de Vilar, the oldest known document to mention the monastery dates from 1059 (FAURE 2012, MATOS 1985).

It was only by the end of the eleventh century that the monastery adopted the Rule of St. Benedict (FAURE 2012, MATOS 2001), which led to an increase of its importance and development. The instability that came to affect the monastery by the end of the 14th century led to a progressive abandonment, decay and, consequently, to a period of vacancy in the beginning the 15 th century.

Almost simultaneously to the extinction of the benedictine monastery, in 1425, the Archbishop of Braga, D. Fernando da Guerra, offered the abandoned monastery to a group of religious men (VINHAS 1998). Led by João Vicente, the physician of the Portuguese Kingdom, the group initiated the Congregation of Secular Canons of St. John the Evangelist, popularly as "Lóios", and began to develop in Vilar de Frades a mission focused on evangelization and assistance to the population, only to be ceased in 1834 with the extinction of religious orders by the Portuguese government.

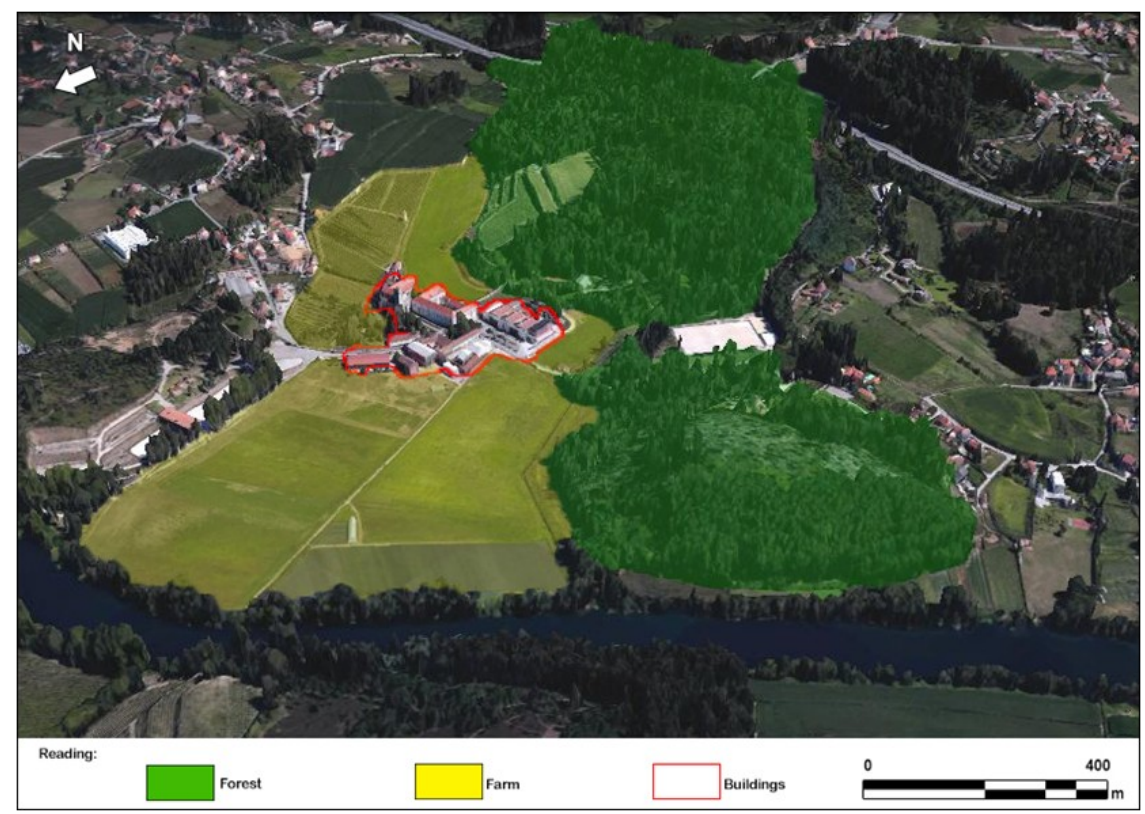

Fig. 1. The complex of the convent of Vilar de Frades.

Fig. 1. O complexo do convento de Vilar de Frades.

\section{METHODOLOGICAL APPROACH}

The archaeological and historical study of wood materials, through its physical remains, has always constituted an endeavour that collides with the perishable nature of wood. Considering this particularity, the methodological approach urged a multidisciplinary approach that converged the theoretical assumptions of Archaeology of Architecture and the History of Construction. Directed

\footnotetext{
${ }^{2}$ As an example, the chronicler refers that in the past existed in Vilar de Frades pine trees with such great width, that three men could not embrace the tree while
} holding each other's hands (MARIA, 1697). 
towards the study of monastic and conventual building construction, it was sought to approach aspects like constructive evolution, the diversity and the utilization of the materials and the interaction between the human actors.

The methodological posture was also based on the recognition of historical buildings as the result of human actions, materialized and stratified in different cultural contexts, capable of being interpreted by the crossing of different types of historical and archaeological sources. Among the building itself as the material source, also the written sources, the graphic sources, and the photographic sources were considered for this specific study (Fig. 2).

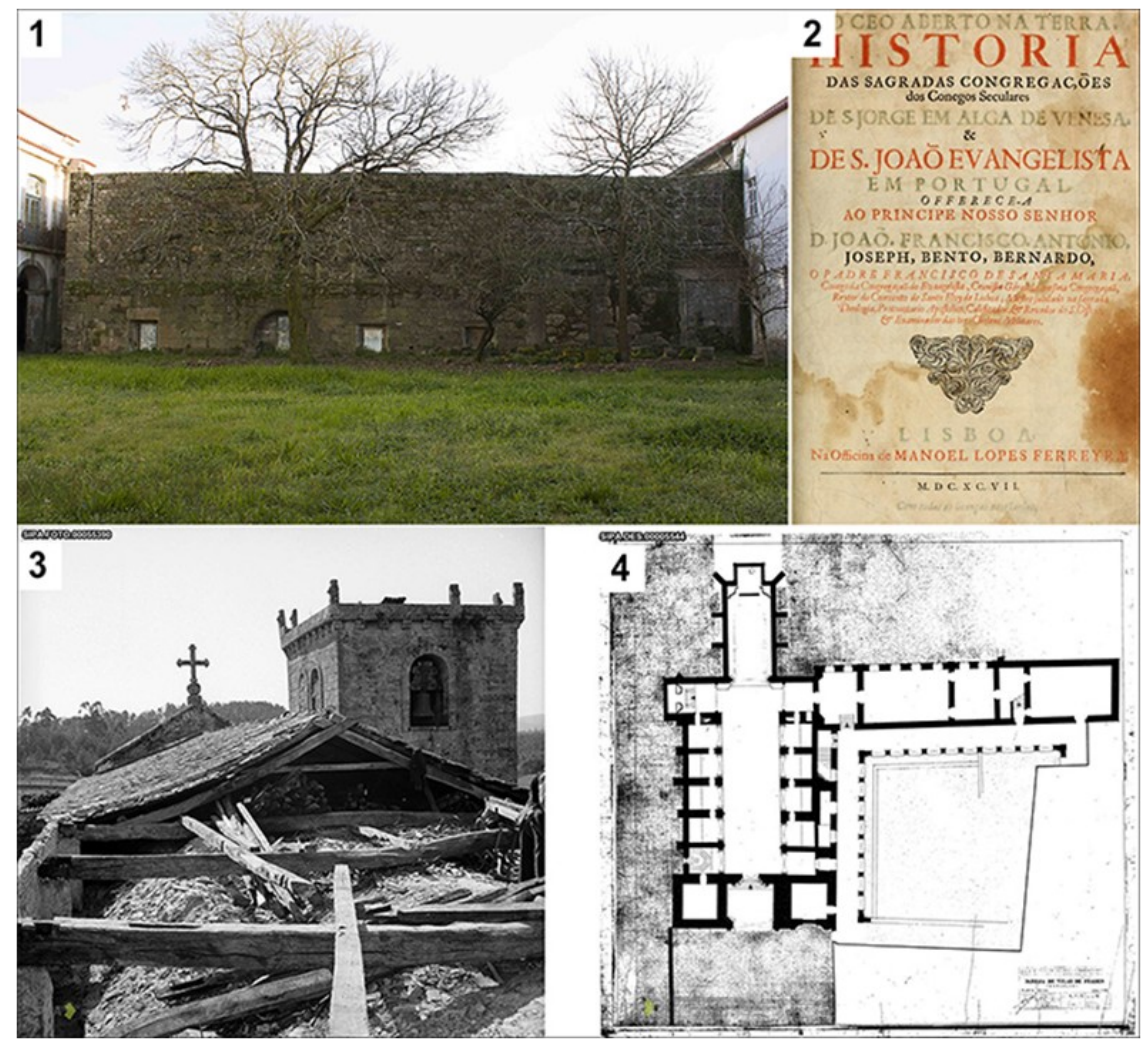

Fig. 2. Examples of the sources used in the methodological approach (1: south wall of the south cloister; 2: "O ceo aberto na terra (MARIA, 1697); 3: Photo of the roof of the church's presbytery (DGEM); 4: plant of the ground floor of the convent (DGEM)).

Fig. 2. Exemplos de fontes utilizadas na abordagem metodológica (1: Parede sul do claustro sul; 2: "O ceo aberto na terra (MARIA, 1697); 3: Fotografia do telhado da capela-mor da igreja (DGEM); 4: planta do résdo-chão do convento (DGEM)).

\section{THE REFERENCES TO WOODWORK IN THE CONVENT (16 ${ }^{\mathrm{TH}}$ TO $19^{\mathrm{TH}}$ CENTURY)}

As expected in a placed occupied since the $11^{\text {th }}$ century, there are numerous references and evidences of the presence and use of wood in the convent of Vilar de Frades. Have wood been used for building construction or for the manufacture of objects like liturgical furniture, the information existing so far only allows us to trace references related to wood in a period between the $16^{\text {th }}$ and $19^{\text {th }}$ century. A time frame that began with the renovation of the medieval monastery (church and south cloister), in the style of portuguese late gothic "manuelino", and ended with the abandonment of the complex in 1834.

Historiography has addressed the study of construction materials sparsely and as a residual matter. The references to woodwork are associated with periods of construction or reconstruction and, in their vast majority, contemplate agreements for the manufacture of liturgical furniture, such as the choir stalls and altarpieces.

\subsection{The $16^{\text {th }}$ century}

The first documented references to the use of wood in Vilar de Frades date before 1520, when the carpenter Bartolomeu Dias built chests for the sacristy and beds for the infirmary (VINHAS 1998). The second one, around 1541, attests the presence of Pero de S. João (the old) in Vilar de Frades to execute the liners, niches and the choir stalls (VINHAS 1998). This two references, although very unspecific, appear however to indicate the absence of differentiation and specialization between the woodworking in building construction and in furniture making. 
Inversely, in the second half of the century, it is already noticeable a specialized designation about the woodworking practitioners in Vilar de Frades. Besides the broader term "carpenter", the references bring up the name of carvers, such as António Pereira, who was hired in 1566 to execute an altarpiece and Bento Loureiro, with whom an agreement was established to carve and line the lateral altarpieces of the church (VINHAS 1998).

\section{2. $17^{\text {th }}$ century}

The $17^{\text {th }}$ century was marked by the reconstruction and renovation of the body of the church due to the menace of collapse. The references related to woodworking are only mentioned near the conclusion of the reconstruction, in 1682, when the convent's rector, Father Diogo dos Anjos, made an agreement with António João Padilha for all of the woodworking in the high-choir. The task included the stalls, the bookshelf and the railing, with only the stalls and bookshelves being preserved in the present (VINHAS 1998). Figuratively, the order of the main door of the church seemed to "close" the reconstruction of the nave. The order was made in 1695 to a master carpenter named António Simão (VINHAS 1998) (Fig. 3).

In the last years of the century re-emerges the woodworking focused on furniture, particularly on altarpieces. A contract established with carvers António Gomes and Domingos Nunes, in 1696, previewed the execution of the central altarpiece and the tribune of the church's main chapel. While, in 1698, the same carvers start to execute the collateral altarpieces and some panels for the walls of the presbytery (VINHAS 1998).

The $17^{\text {th }}$ century is also characterized by the imported species used as raw material. The so called "madeiras de lei" or "hardwood", whose use is related, in large part, to durability, are present in Vilar de Frades. Species like "rosewood" or "blackwood", constitute the raw materials found in the stall and shelf of the high-choir, while in the main door of the church we find the presence of a wood called "angelim" (Fig. 4).

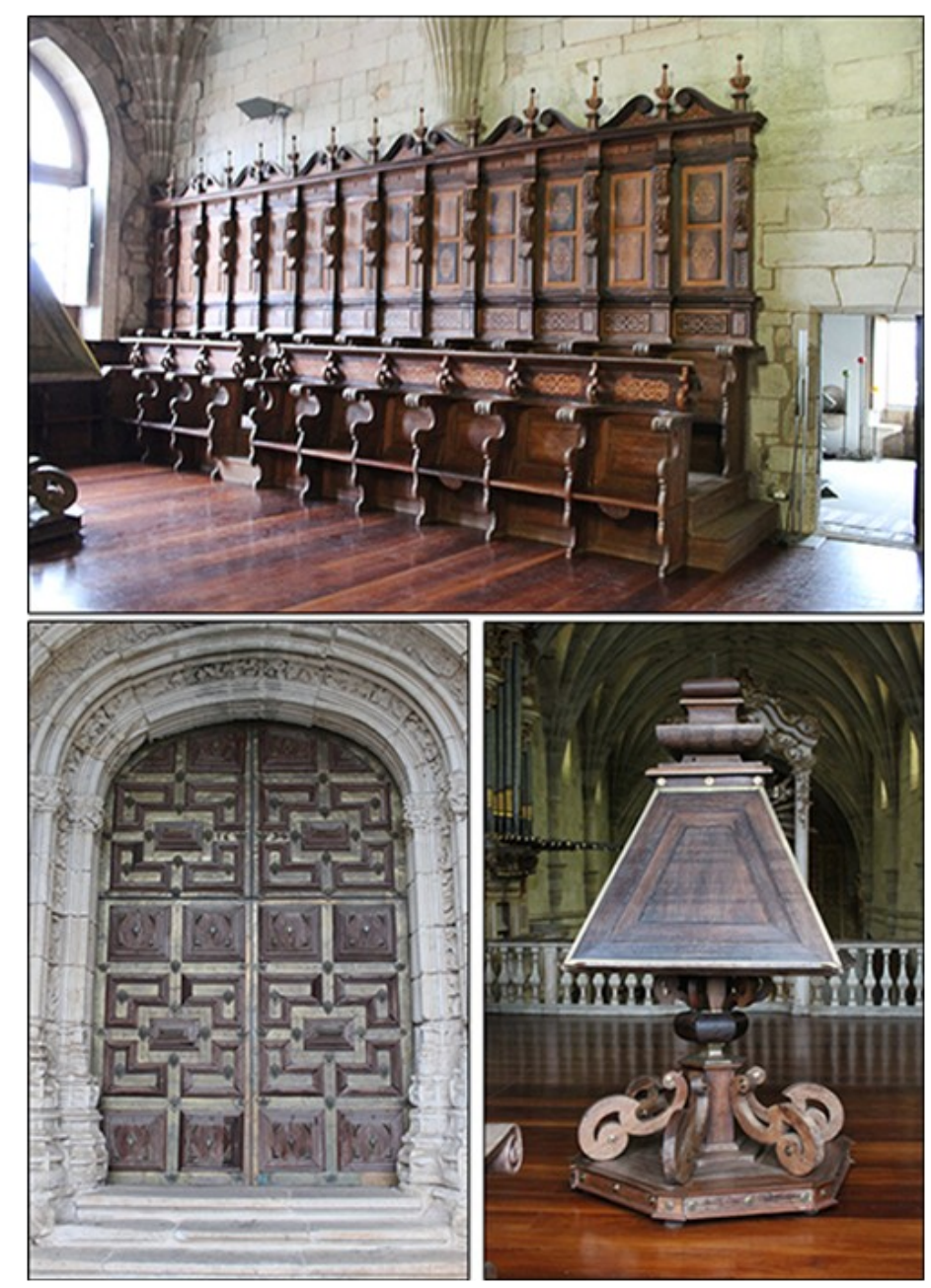

Fig. 3. The choir stall, the main door of the church and the choir shelf.

Fig. 3. O cadeiral do coro, a porta principal da igreja e a estante do coro. 

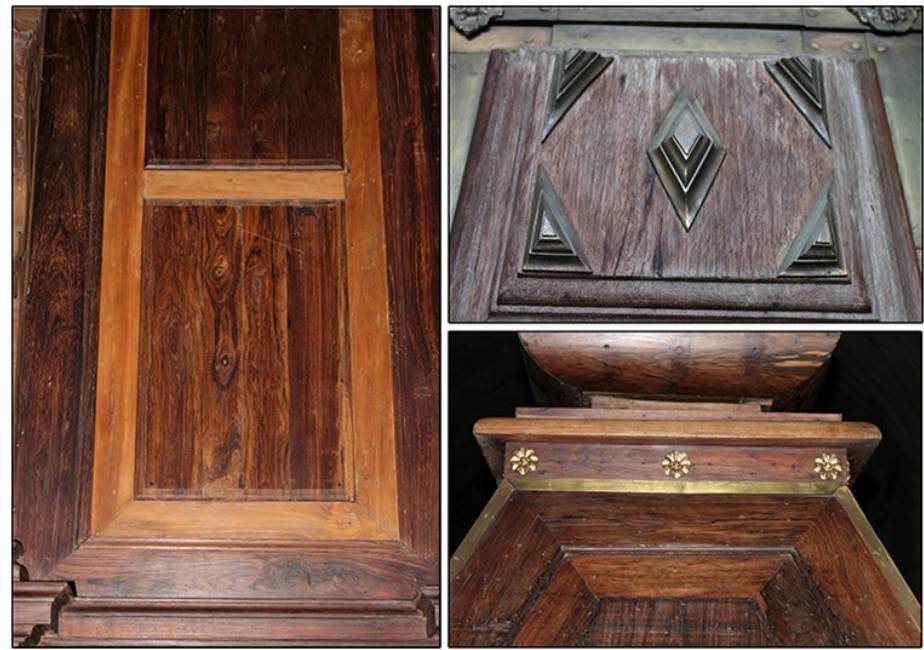

Fig. 4. Examples of rosewood and "angelim".

Fig. 4. Exemplos de jacarandá e angelim.

\section{3. $18^{\text {th }}$ century}

From the need of expansion of the domestic area, the construction of a new cloister, located at southwest of the church and called "terreiro dos cabedais" (Fig. 5), runs between 1704 and 1706 and all of the carpentry work of the new body is executed by the carpenters Miguel Martins and Manuel de Sousa Lemos (VINHAS 1998).

The agreement for the work involving carpentry contemplated aspects such as the acquisition and transformation of raw materials, in which the encumbrance of cutting and sawing chestnut trees was part of the responsibilities of the carpenters. Their plan, in sole terms, contemplated the placing of all of the beams and respective floors, doors, windows, room divisions (which used a noggin technique), ceilings and the frames of the rooftops. In the second half of the eighteenth century, under the administration of Rector Francisco de Santa Maria, the presbytery's stalls were produced for making a choir, in a style already symptomatic of the presence of the neoclassical influence in the liturgical space (Fig. 6).

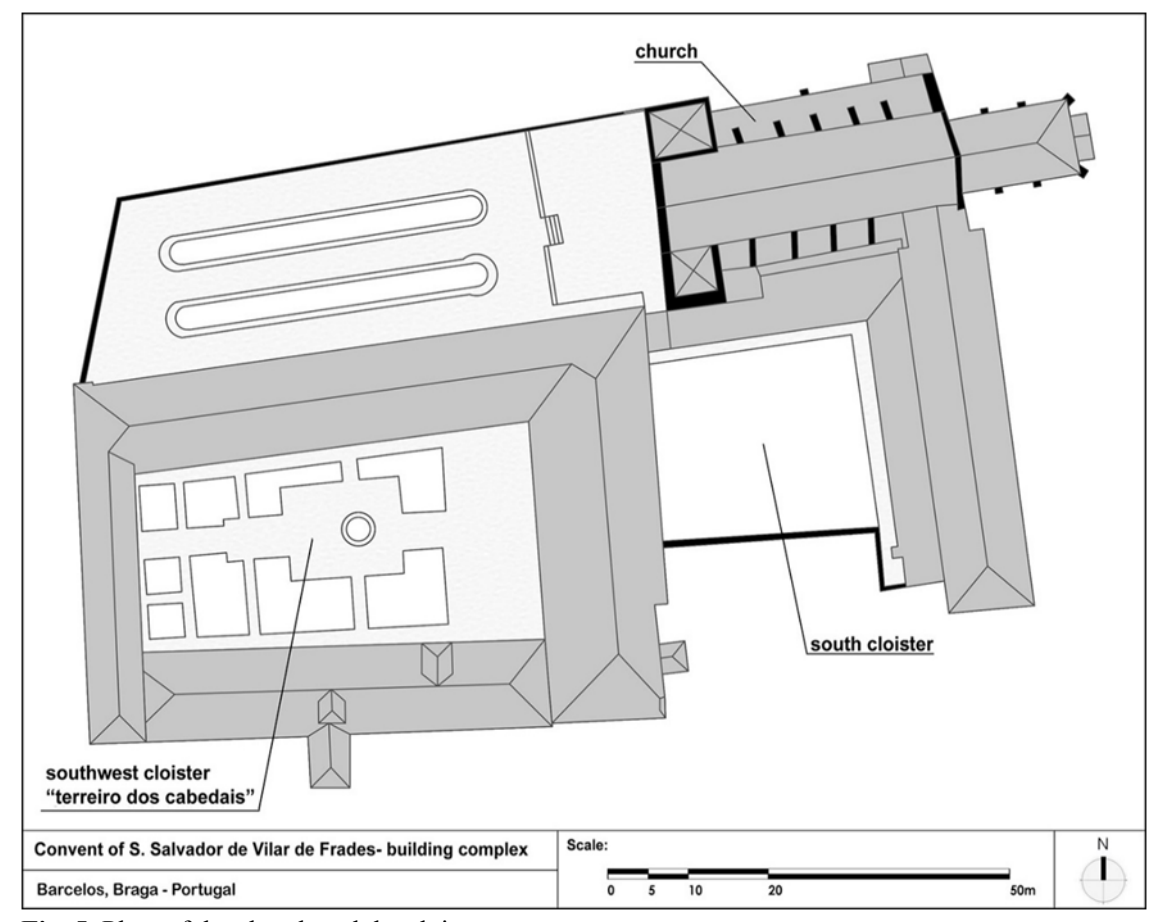

Fig. 5. Plant of the church and the cloisters.

Fig. 5. Planta da igreja e dos claustros. 


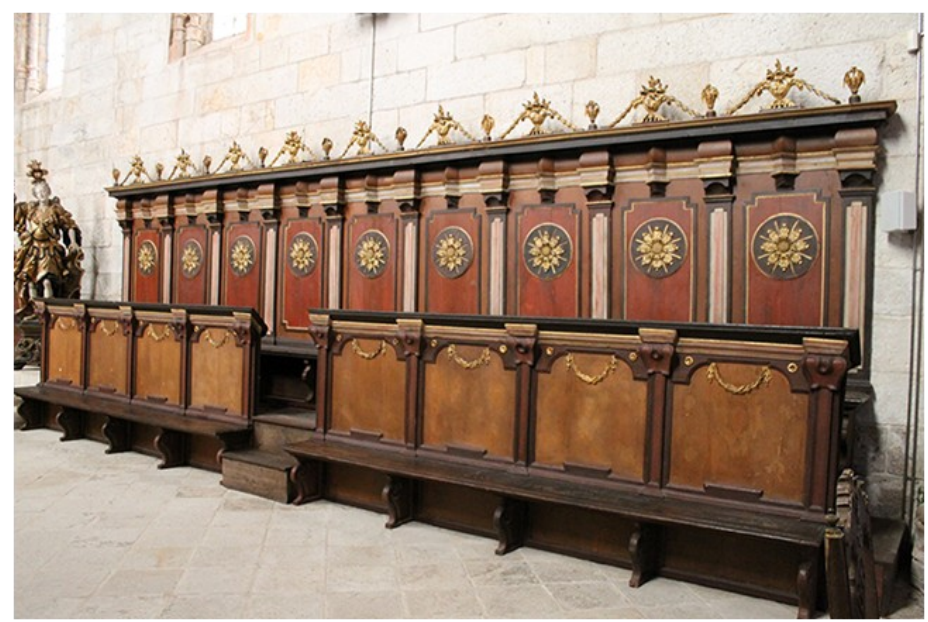

Fig. 6. The Choir stall in the presbytery of the church.

Fig. 6. O cadeiral do coro na capela-mor da igreja.

\subsection{The $18^{\text {th }}$ and $19^{\text {th }}$ centuries}

Between 1796-1797, Rector Father Manuel de S. Tiago e Silva initiated a complete renewal of the $16^{\text {th }}$ century cloister that would never be completed (VINHAS 1998). The sources omit how the constructive process went and we are still unable to identify the responsible for woodworking. Nonetheless, the north and east wings, containing the sacristy, the refectory and the novitiate dormitory, still preserve several wood and wood related remains, going from the window frames and the intricate ceiling system in stucco of the sacristy to the noggin divisions of the cells, the chapel roof lining in the dormitory and the frame for the novitiate dorm roof (Fig. 7).
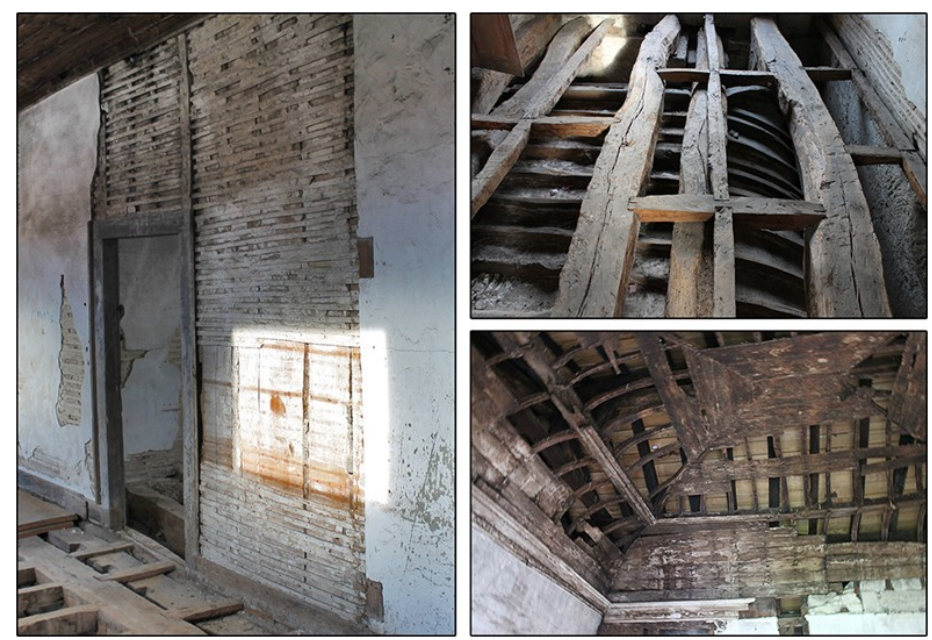

Fig. 7. Details of the wood used in the structures of the dormitory of the south cloister.

Fig. 7. Detalhes da madeira utilizada nas estruturas do dormitório do claustro sul.

\section{THE BEAM SYSTEMS OF THE $16^{\mathrm{TH}}$ CENTURY}

As already mentioned, being wood one of the most used and ephemeral material used in the medieval and modern age construction, in Vilar de Frades the data about wood, apart from being mainly centred on written sources, suffers from somewhat vague descriptions on its use on constructive systems and results in little information.

Missing aspects like the source and type of the raw material used, as well as the transformation the raw wood underwent until its final form, make it difficult to fully reconstitute the use of wood in the construction of Vilar de Frades. Additionally, the connection often established between the production of furniture and the constructive moments directs us to a very specialized type of work, like choir stalls and sacristy chests.

Despite their importance and intrinsic artistic value, these objects should be regarded as artefacts of liturgical importance, more related to space con- 
ception and functionality of the interior divisions of the convent than to the constructive process.

However, in Vilar de Frades there are other types of evidences that enable an indirect approach to the analysis of wood and constructive systems, like floors and ceiling structures, that still have elements fossilized in the building. As an example, in the south cloister of the convent there is a wall dating from the $16^{\text {th }}$ century (Fig. 8), whose presence is fundamental because its stratification preserves the different periods of the constructive evolution of the cloister. At first sight, it can easily be observed that the stratigraphic complexity relates to different contexts architecturally dissonant that translate distinct chronological building phases.

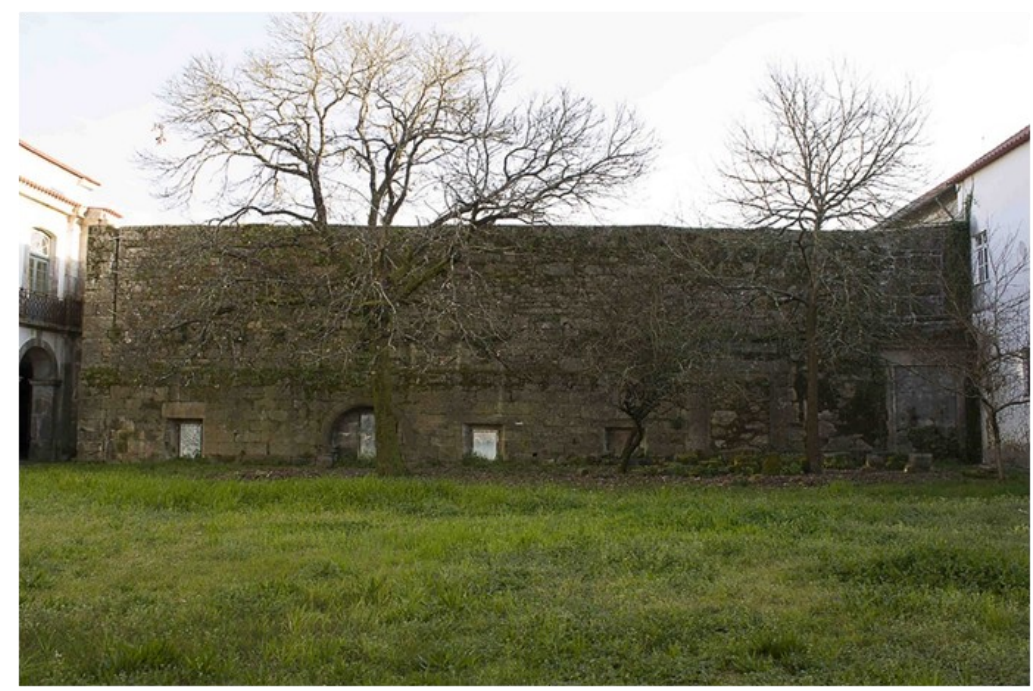

Fig. 8. The south wall of the south cloister, dating from the 16th century.

Fig. 8. A parede sul do claustro sul, datada do século XVI.

The cloister built in the mid 1500's is mostly described in an aesthetical manner. The written descriptions emphasize the visual impact of the marble elements, like the columns or the fountain that was added in the end of the century (MARIA 1697), relegating to a second plan the structural characterization of the cloister.

The architectural elements visible on the wall resemble a structure divided in two floors, with various openings and an arcosolium highlighted in the ground floor. Other characteristics subjacent to the architectural elements rely on the fact that the lower openings today are at the height of the ground, indicating in the past a lower circulation floor $^{3}$ (Fig. 10).

Besides the architectural elements typical from the $16^{\text {th }}$ century, this structure resembles several other architectural elements whose placement disrupts the organization of the original building. Moreover, it is clear that it comprises a group of distinct actions, related at least to two different constructive phases.

The retrieved archaeological data enabled an interpretation for the dissonant architecture that attributed two distinct phases dating from the $16^{\text {th }}$ century (FAURE 2012). The older phase, dating at least from the first half of the $16^{\text {th }}$ century, includes the openings that have become dissonant with the elevation of the ground level. They would incorporate the south wall of a building that evolved from that wall towards the north. In its interior, at ground level, it would have been constituted by a wide compartment with a tiled floor (FAURE 2012).

In the upper floor, the floor would have been made of wood, and the several openings show the existence of at least three cells, related to a dormitory function.

Although we are unable to find any wood remains in this wall from the $16^{\text {th }}$ century, the midsection between the two floors reveals a group of closed orifices that were possibly part of the support of the upper floor (Fig. 9). Displayed in a band, these holes (Fig. 12), were possibly part of a beam system where the beams recessed directly in the wall without groundsills and were probably reinforced with billets, placed at minor intervals to avoid oscillations on the floor. Moreover, the choice of this type of beam system also echoes in the interpretation of the ground floor. Consisting the interior of the ground floor, as already stated, of a large open space, this interpretation correlates to the presented beam system, since this type of beams were more suitable for wider spaces (COSTA 1955) (Fig. 11).

${ }^{3}$ A fact already proven by the archaeological interventions that underwent between the last decade of the XX century and the first one of the XII century (Faure, 2012). 


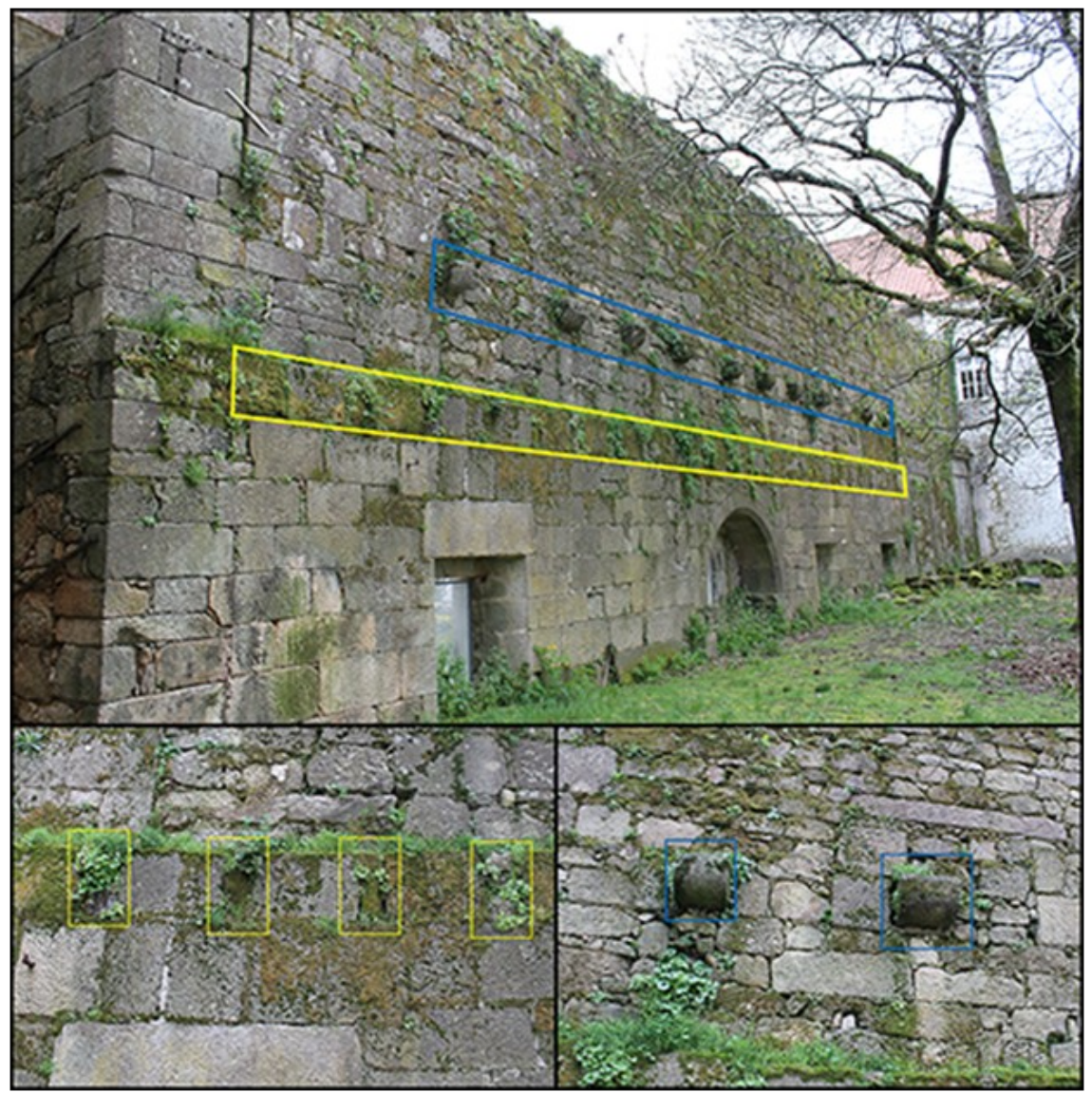

Fig. 9. Marks and evidences of the different systems from the first half of the 16th century (yellow) and prior to the sencond half of the 16th century (blue).

Fig. 9. Marcas e evidências dos diferentes sistemas da primeira metade do século XVI (amarelo) e após a segunda metade do século XVI (azul).

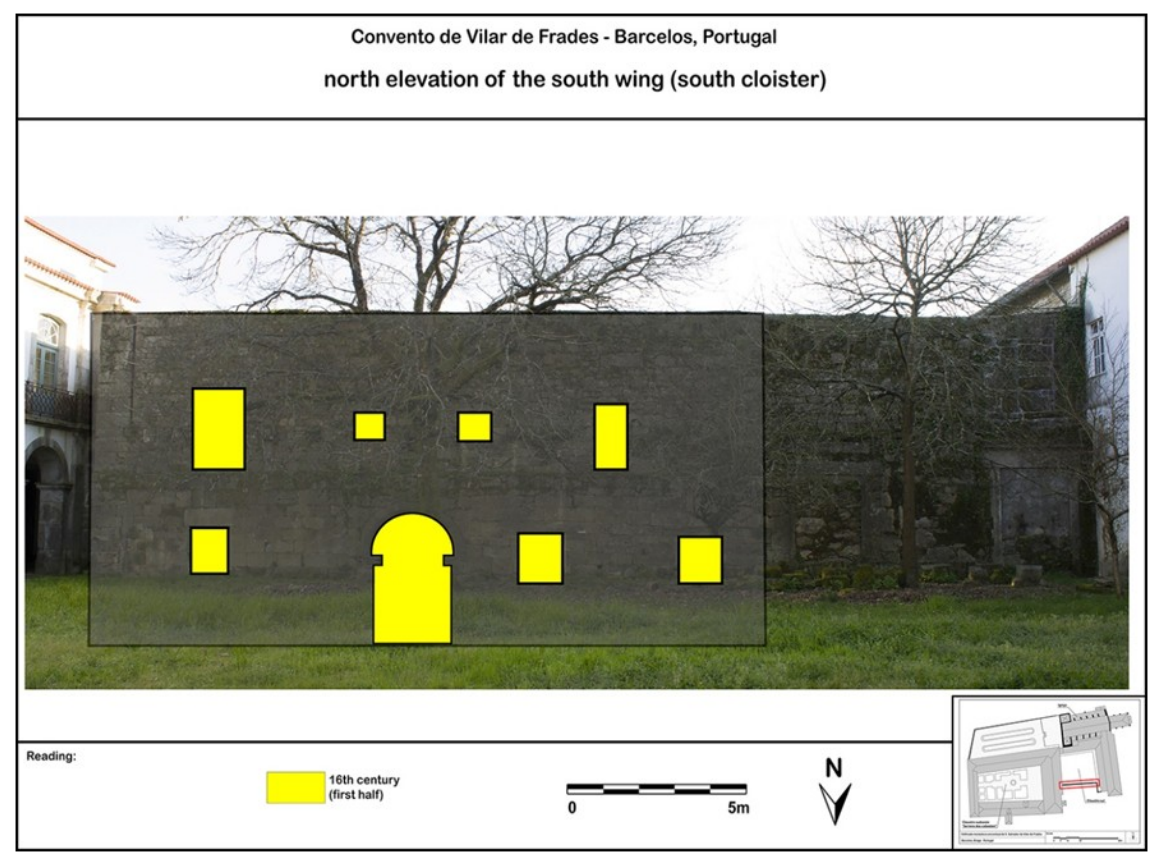

Fig. 10. Scheme of the architectural organization of the first half of the 16th century.

Fig. 10. Esquema da organização arquitetónica da primeira metade do século XVI. 


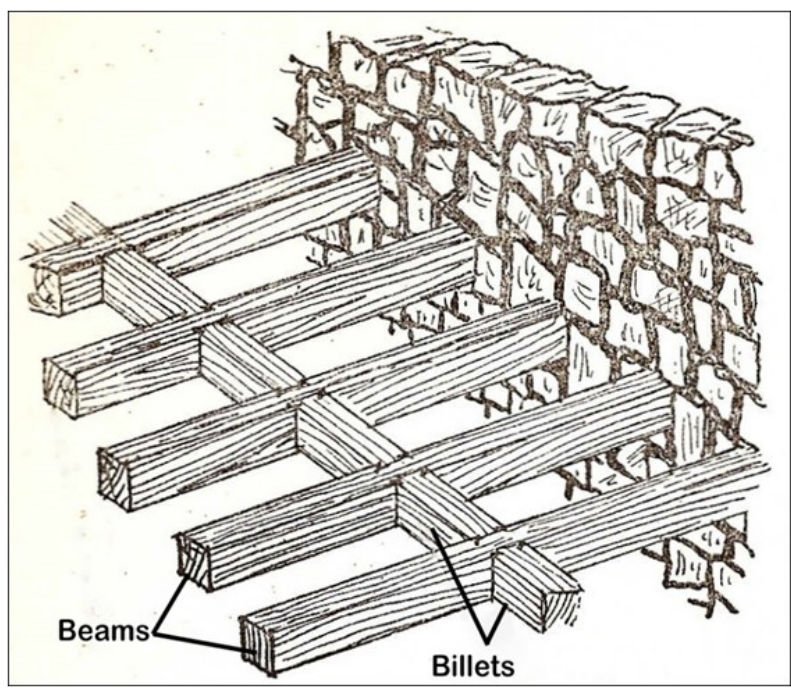

Fig. 11. Drawing of a beam system recessed on the wall (adapted from Francisco Costa, 1955).

Fig. 11. Desenho de um sistema de vigamento encastrado na parede (adaptado de Francisco Costa, 1955).

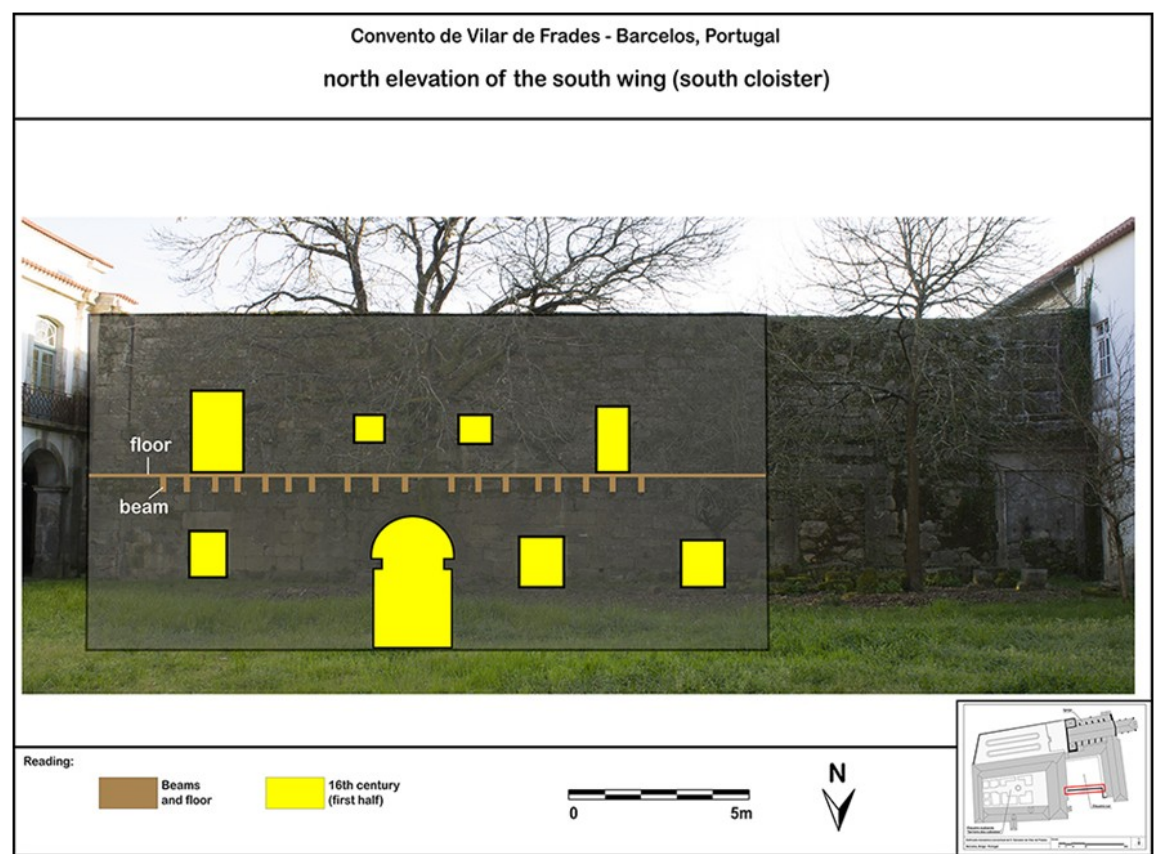

Fig. 12. Scheme of the beam system (in section) of the building in the first half of the 16th century.

Fig. 12. Esquema do sistema de vigamento (em secção) do edifício na primeira metade do século XVI.

With the construction of the church, in the beginning of the $16^{\text {th }}$ century, its implantation at a higher height than before probably formed a dislodgment in the space to the south of the church and in the building to which the wall in analysis belonged. As a result of this disarticulation, the second constructive phase perceptible in the wall translates a change in the configuration of the area in the south side of the church and a reconstruction of the cloister space between 1555 and 1559 (FAURE 2012).

The archaeological interpretation demonstrated that during this period were made founda- tions that ruptured the tilled floor of the anterior building and the zone was landfilled in order to match the ground of the church (FAURE 2012). The foundations were meant to support a structure based on columns, as the anterior building was partially destroyed. What was in the beginning of the century the south wall of the building, was turned into the north wall of the south wing of the cloister. The built space, now evolving from this wall even further to the south, was turned into a cloister wing with an open balcony facing the church. Due to this rearranging, all of the older 
openings were closed and the result was a much more dense structure with only two doors in the ground floor and a large portal with an segmental arch (FAURE 2012) (Fig. 13).

With all of these transformations and the emergence of new built space, the constructive systems were also modified in order to meet the requirements of the building. The set of corbels (Fig. 9) present in the wall is an evidence and a result of the promoted changes and it is part of a beam system completely distinct from the older one. The upper floor of the south wing, now in a form of a balcony, should contemplate a beam system supported by the wall and the arcade of the inferior floor.

Inside the new space conception, considerably narrowed, the beam system should have consisted in a group of thick wood beams, placed more distantly than in the previous system and transversally to the wall, uphold by the prominent stone corbels (Fig. 14)

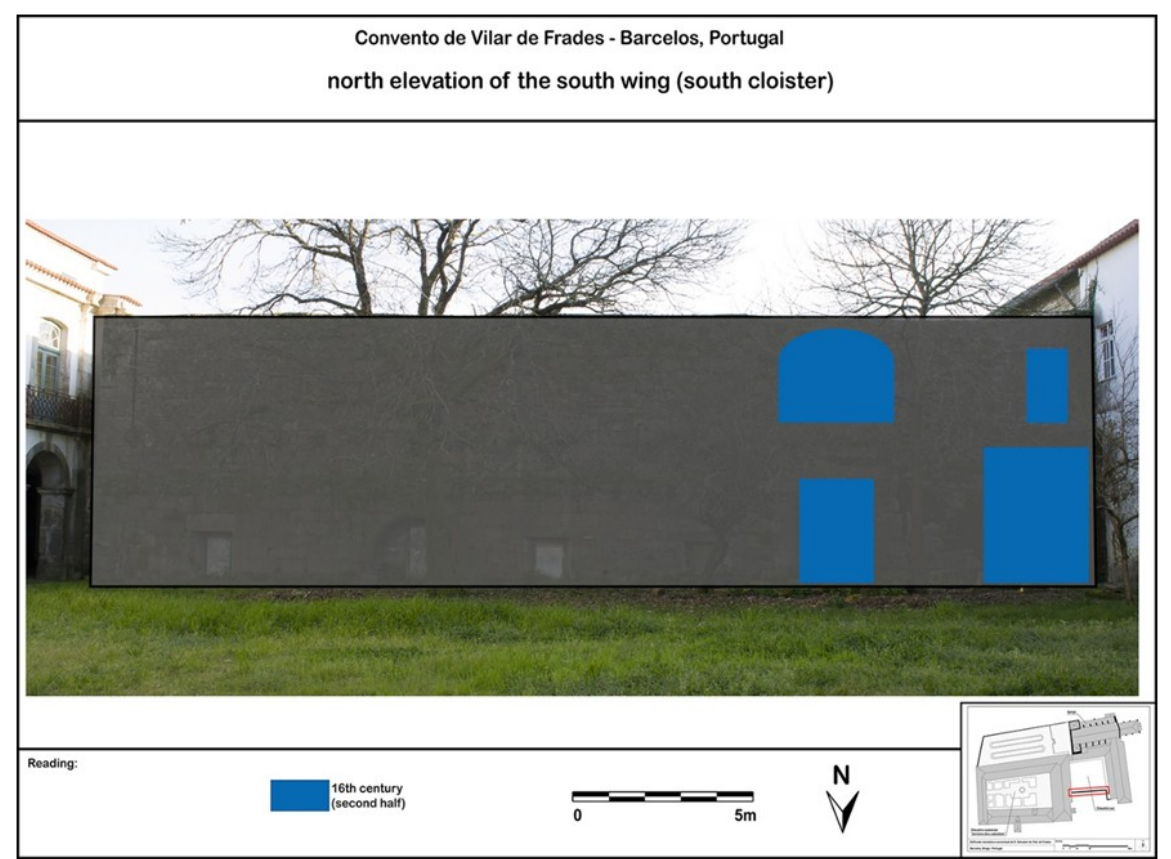

Fig. 13. Scheme of the architectural organization from the second half of the 16th century and on. Fig. 13. Esquema da organização arquitetónica a partir da segunda metade do século XVI.

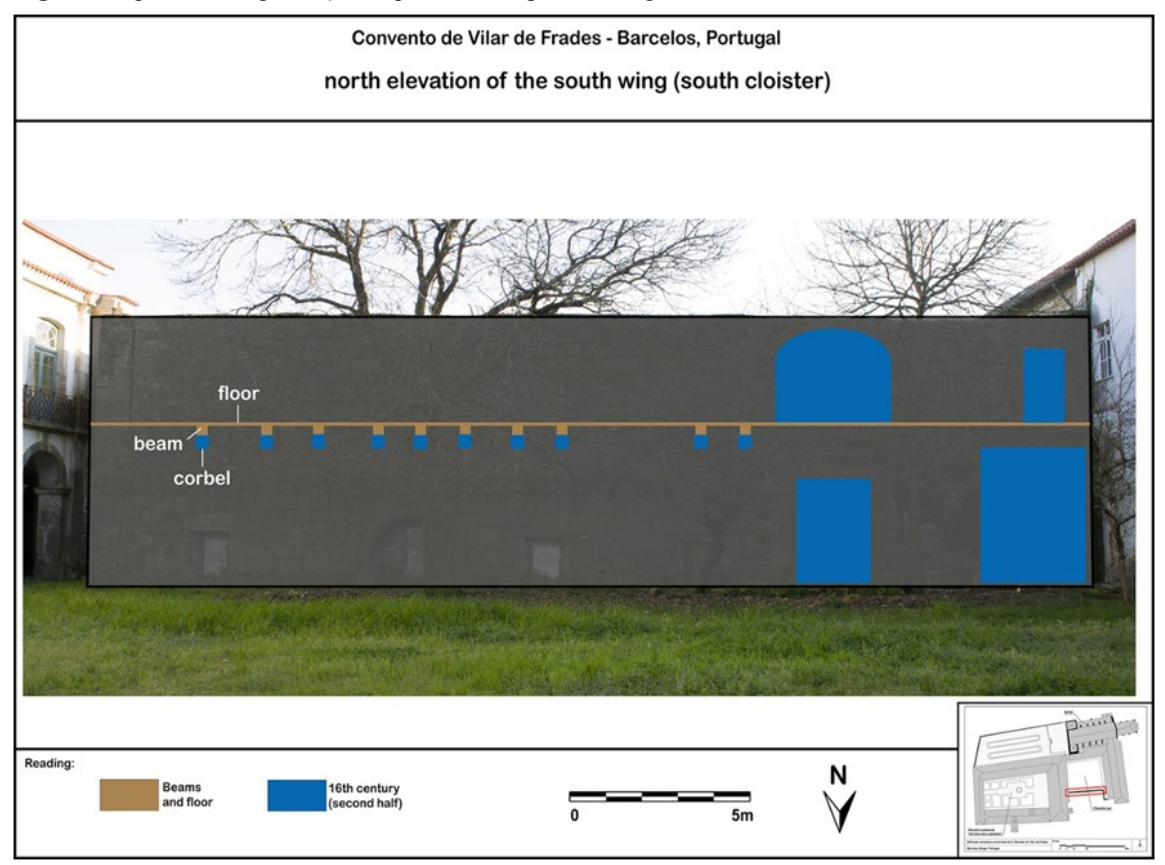

Fig. 14. Scheme of the beam system (in section) of the building from the second half of the 16th century.

Fig. 14. Esquema do Sistema de vigamento (em secção) a partir da segunda metade do século XVI. 
Besides the constructive outburst that occurred in the cloister during the $16^{\text {th }}$ century (FAURE, 2012), some of the other remains associated to this wall and particularly to the upper floor system, are also mention worthy for the comprehension of the evolution of the cloisters in Vilar de Frades (Fig. 15).

At least two of the now closed doors on the south wall are directly connected to the south wing of the southwest cloister. Having this wing been completed probably in the beginning of the $18^{\text {th }}$ century (VINHAS 1998), the upper door located near the top right angle is aligned with the corbel system, a fact that might indicate the use of this beam system at least until the $18^{\text {th }}$ century.
In a similar form, in the east wing, built subsequently during the transition between the $18^{\text {th }}$ and $19^{\text {th }}$ centuries (VINHAS 1998), resembles another corbel, not in use, that also aligns with the set of corbels of the south wall. More than being relevant for the characterization of the beam system of the cloister of the $16^{\text {th }}$ century, it also could be essential to assimilate to what extent the unfinished cloister of the $19^{\text {th }}$ century reutilized and incorporated part of the structure of the $16^{\text {th }}$ century. Although not enough to determine a proper interpretation in this sense, it opens a new perspective of investigation and a prompts us to an even deeper analysis of the constructive remains.
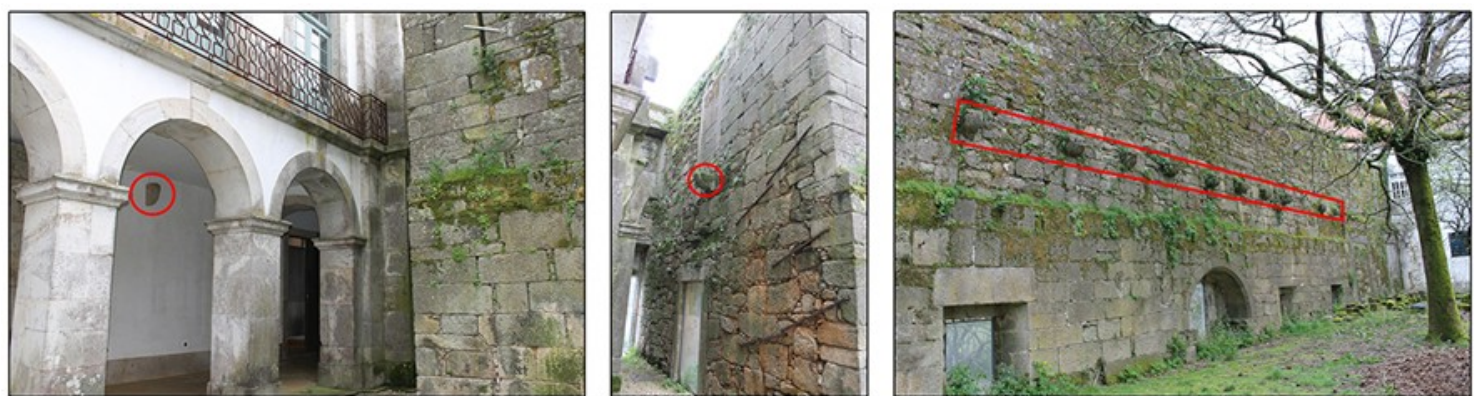

Fig. 15. Corbels identified on the south cloister. East wing (left), east wall of the south wing (centre) and south wall (right).

Fig. 15. Mísula identificadas no claustro sul. Ala este (esquerda), parede este da ala sul (centro) e parede sul (direita).

\section{CONCLUSION}

In conclusion, it is a fact that wood constitutes one of the most utilized resources throughout the historical course of Vilar de Frades. Being in construction, furniture, or in the vast forms of application in the quotidian of the convent, this wide utilization allowed us not only to elaborate an overview of its use over time, but also to essay other approaches and thus engaging in a qualitative step in the multidisciplinary study of wood on monastic and conventual building construction.

Looking at the results obtained in this first approach, while there is a latent awareness that the conserved remains, mostly furniture, have an exceptional character, they do not express the probable preponderance of wood in the building construction of Vilar de Frades. Among the obstacles faced during this approach, most of them came from problems intrinsic to wood and historical buildings. The perishability, the effects caused by abandonment, restoring, consecutive renovations and destructions, revealed an amount of complexity and voids of information that made impossible to properly incorporate some of the existing wood remains. The impact and the effects caused by interventions like the ones made by the Direcção Geral dos Monumentos e Edifícios Nacionais
(DGEMN) during the twentieth century, were responsible for multiple substitutions, patches and restorations. These actions, made mostly on the roofs, conditioned the approach since they were made with a purpose of "imitation"

On a secondary level, aspects like the provenance and the acquisition of wood as a raw material to be used in building construction is a part of the process still out of reach, as one of the very few examples mentions that the responsibility of acquisition of the wood belonged to the carpenter or the carver.

However, the chronicles express that the woods inside the convent's fence were privileged places for the takedown of trees like chestnuts, oaks and mostly pine trees and that the friars provided, inclusively, the supply of wood logs to others places.

Concerning the technical, artistic and human components, it is realizable that from the $16^{\text {th }}$ century and forward it is noticeable a growing specialization of woodworking that starts to include, besides "carpenters", "ensambladores" (a type of assembler for woodworking) and "entalhadores" (carvers). However, it is also visible that the hierarchy inherent to the craftsman's organization implicit on the "master" prefix, occurs

\footnotetext{
${ }^{4}$ The Direcção Geral dos Monumentos e Edifícios Nacionais (DGEMN) was a cultural division created to act upon the preservation of historical buildings and monuments under an ideology of restoring the original architecture of the buildings, whence to illustrate the origin of Portugal as a nation.
} 
occasionally to describe the bidder of the contract and not necessarily the executant of the work. Even more so because the sources are silent about the number of apprentices and common workers which would certainly integrate this associations of workers.

At last, the analysis of the wood beam systems indirectly through the existing remains enabled us to identify the use of different solutions that have a chronological meaning and a connection to the dimension of the built space.

Being a preliminary approach, the analysis provided a long-term overview of the use of wood and permitted to established new research lines concerning the use of wood in conventual building construction along the history of Vilar de Frades. So, in conclusion, one of the most expressive aspects about wood is the constant dialectic that it establishes with other construction materials like stone, as well as its wide range of utilization and applications. This characteristic makes it the most plastic and malleable element diffused in the liturgical space as much as in the domestic, from the mere utilization in structures to the production of cult objects.

\section{BIBLIOGRAPHY}

Costa, F. P. da. (1955). Pavimentos de Madeira. In Enciclopédia Prática da Construção Civil, Portugália Editora, pp.1-16.

Faure, F. G. C. L. M. (2012). Casa de Deus e de Homens uma leitura arqueológica do Convento de S. Salvador de Vilar de Frades. Porto: Universidade Pessoa.

MARIA, F. de S. (1697). O Ceo Aberto na Terra. Lisboa: Na Officina de Manoel Lopes Ferreyra.

Matos, S. (1985). Areias de Vilar. Das suas origens. Barcelos Revista, 2, 25-36.

Matos, S. (2001). Vilar de Frades e o seu património. Barcelos: Edição de Autor.

VINHAS, J. (1998). A Igreja e o Convento de VIlar de Frades. Das origens da congregação dos Cónegos Seculares de S. João Evangelista (Lóios) à extinção do convento. Barcelos: Junta de Freguesia de Areias de Vilar. 